\title{
The Living Gospel
}

By Luke Timothy Johnson

London, New York: Coninuum

ISBN 0826474802

Price: R120

Pieter GR de Villiers

Free State University

Bloemfontein

\section{SPIRITUALITY AND NEW TESTAMENT STUDIES: A NEW PUBLICATION ON THE ART OF CHRISTIAN LIVING, WITH A SPECIAL FOCUS ON HOMOSEXUALITY}

\begin{abstract}
This article discusses the latest publication of Luke Timothy Johnson, The Living Gospel in terms of its contents, and, especially in terms of its use of Spirituality. It then focuses on his discussion of homosexuality in order to illustrate the implications of the growing trend towards Biblical Spirituality.
\end{abstract}

Key Words: Homosexuality, New Testament Studies, Spirituality

Luke Timothy Johnson has become know for his widely used introduction to the New Testament, The Writings of the New Testament (Minneapolis: Fortress, 1999) and also as critic of the Jesus Seminar (The Real Jesus. HarperSanFrancisco, 1996). ${ }^{1}$ His new book is written for readers outside the academy, according to the introductory notes, interpreting the Bible "for the life of the church in a manner that is at once loving and critical, challenging and charitable" (vii). It is, though, not a "popular" book in the sense that it contains sermon-like or sentimental reflections on the practical meaning of Biblical texts. Written in a lucid and simple way, it is, perhaps, one of the best examples today of how solid Biblical scholarship can be made available and accessible (and unpatronisingly) to those outside the field - not only lay people, but also theological colleagues and ministers outside the field of New Testament studies.

\footnotetext{
Johnson, despite his criticism, often distances himself from fundamentalist critics of the Seminar. His unique contribution is furthermore clear, for example, from the fact that he differs from other critics like NT Wright, who critiques the Seminar from within historical scholarship. Johnson's own position on the historical Jesus borders on a minimalist position, but he deflects the impact of this with his experiential interpretation of the New Testament. He delineates the nature of faith as an experiential response to powerful events in the resurrection rather than as a belief in some historical information and/or facts.
} 


\section{Addressing the Issues and Challenging to Action}

The book is topical in many ways. It addresses in a refreshing manner such seminal issues like war $^{2}$ by analysing James 3:13-4:10 (on "The things that make for peace" - 83-90). Johnson develops this analysis by a thorough exegesis of Graeco-Roman perspectives on envy, ${ }^{3}$ arrogance and friendship before unmasking the warlike face of contemporary society with its troubling and dangerous capitalism (87ff). The book also addresses the topic of body, so prominent in our times, with a beautiful discussion of the human body (125-126), marriage, specifically relating to sexuality (67-72) and an insightful discussion on homosexuality (cf. further below). In a strongly worded article entitled Jesus and the little children (51-58), the author speaks out on the scandal of child abuse in the church. Having noted that the scandal is less about sex than about abuse of power, he writes:

I have yet to see any Bishop state clearly how and why the predatory behavior of the clergy and the self-protecting cover-up by bishops is an abuse of power that requires both real change in the way things are done in the Church, and a real change in the people who do things in the church (58).

His own progressive position is clear:

Unless women are ordained, unless married males are ordained, it is unlikely that the chasm between the perceptions of the laity on this matter and those of the clergy will be bridged (52).

He also looks at other topical issues, strongly relevant to our Christian context, such as material wealth, the quest of the historical Jesus and the politicizing of Christianity (e.g. How does Jesus save us?, 191-99). In all these discussions, his systematic mind penetrates to some fundamental characteristics of modern societies. Thus he investigates the notion of sacrifice in terms of the revulsion that it elicits among many theologians who associate it with the slaughter of animals and the exploitation of women (27). Confirming the New Testament's criticism of ritual sacrifice, he nevertheless argues for the continuing relevance of the motif for a Christian lifestyle by noting how it is developed in a new way in it:

The truth expressed by sacrifice is that humans are profoundly dependent creatures whose life is most enhanced when it is shared, even at great cost, (31). ${ }^{4}$

We should not lose this important insight because of some questionable characteristics of contemporary societies. We should be aware of the deformed nature even of certain forms of spirituality that are so popular because of the spirit of the times and that are challenged directly by the notion of sacrifice:

Ours is an age that has a strong bias in favour of self-fulfillment and personal empowerment, partly in response to the perception that traditional religion has served to suppress legitimate self-development and expression... So pronounced are these tendencies among some contemporary Christians that their attitudes are hard to distinguish from oldfashioned selfishness, even when they are clothed in forms of "spirituality" that make self-centering and tranquility absolute good.

"The Letter of James proposes that human conflict and violence is directly connected to disordered and conflicted desires" (84).

"James seems to say that envy lies at the root of social disorder, violence and war" (86). His concluding remarks on 89-90 provide an outstanding example of an untypical, non-moralistic portrait of the spiritual life. It also underlines his awareness of the social implications of the gospel.

4 This remarked is followed by a simple, but moving example (31) of the ongoing relevance of sacrifice in which he notes how an Afro-American athlete, on acquiring fame and wealth, first of all seeks to take care of his mother. 
A remark like this reveals both his criticism and his appreciation of spirituality. Whilst he distances himself from skew forms of spirituality, he develops themes like that of sacrifice that are seminal in spirituality.

Johnson systematized these topical essays in terms of their specific focus on theology, Scripture and more particularly (the historical) Jesus. Those who are acquainted with his other, more scholarly publications will recognize that he is presenting that work in an updated, but more concentrated form. The essays on Wealth and Property in the New Testament (19-26), How Saint Luke Affirms the World (119-28) and How Saint Luke Challenges the World (129-38) thus reflect some of his research developed elsewhere (e.g. in his The Writings of the New Testament). At the same time, though, an essay like the one on Luke's affirmation of the world, moots perspectives on the human body in terms of the belief in creation that is not only new in terms of his work, but is at the same time exceptional in terms of the discipline and, for that matter, for contemporary society. The book thus provides unique examples of how texts should be read - for instance, his brief explanation of the theological meaning of the dominant motif of prophecy in Luke-Acts (130-1).

He addresses topics that are controversial (the resurrection) or speaks about traditions that are becoming increasingly difficult or unpopular (the worship service and preaching), pointing out their significance without regressing in a fundamentalist, restorative mode. His remarks on the worship service as the preeminent locus for learning Jesus, for example, provide valuable challenges to contemporary trends that tend to devalue it (Learning Jesus in Liturgy 169-176).

His remarks are by times creative, as, for example, when he suggests that the intimate revelation concerning Jesus' identity as God's beloved Son came through the experience of prayer noted in Luke 3:21 (136) or when he writes about preaching as God speaking in liturgy (Discerning God's word, 43-50). Sometimes they are daring and bordering on the completely new in terms of fundamental theological convictions. Thus, in one of the most outstanding essays - on suffering - in this book, he writes:

We catch sight of a life within God that can grow by encompassing God's own creation. We can even suspect that the trinitarian God that shows us glimpses of his inner life through the veiled revelation in creation, salvation, and sanctification, may be the supreme system in disequilibrium, the ultimate expression of the truth that suffering change is the price paid for life to grow. To say such things is to skirt the edges of orthodoxy, yet our experience of Jesus and the gift of God's Spirit gives us boldness (17). ${ }^{5}$

\section{Biblical Studies and Spirituality}

With this book, though, an important new trend in New Testament studies is confirmed. Two aspects are important in this regard.

\section{Historical and Theological Approaches to the Study of the Bible}

In recent times Biblical Studies as a discipline had been characterized by an emerging focus and debate on the theological interpretation of Biblical texts. ${ }^{6}$ This included canonical

\footnotetext{
Note the telling reference to experience here.

This is not the place to debate this matter, except to point out briefly that contemporary New Testament scholarship seems to move in three directions: there is a strict historical approach (developed, for example, in the Jesus Seminar). This is then developed into a wider, history of religions approach where the history of early Christianity is studied as part of a larger framework of ancient religions. Finally, there is a group of
} 
criticism that interpret Biblical texts in the light of the canon as a collection of books of faith. One example of this was the much discussed book of Watson (1994), once again with an informative title, Text, church and world: Biblical Interpretation in Theological Perspective. In it, Watson referred to the commitment of much of contemporary biblical scholarship to secularity and to a body of rules for biblical interpretation that excludes faith as a subjective, private orientation from research. This book intended to point out the problems of that position and to develop the relevance or even the necessity of theological insights to understand the Bible. Watson specifically notes "that the historical-critical paradigm seems to condition its practitioners to believe that the biblical texts are unable to bear very much theological weight" (Watson 1994:12-13).

It is thus not the historical approach, but the way in which it was used and applied, that is being debated. Johnson's work, for example, with all its criticism of some historical readings of the Bible and his insistence on reading the text in terms of its link with the church, assumes and implements the historical critical approach in a consistent, sometimes even radical manner. He would, for example, note with historical precision how Luke's texts can only be understood within first-century Mediterranean culture and as typical of ancient historiography (121; cf. also 21-22). Applying the hermeneutics of suspicion, he argues that the Gospel authors deliberately downplay John the Baptist's independent ministry, revealing their ideological predisposition regarding other groups (114). Johnson also underlines plurality and diversity in the New Testament (119 - The Gospels "are to be valued as much for the ways in which they diverse as for the ways in which they agree"), taking over significant historical insights that were developed in the discipline in recent years.

For Johnson historical knowledge of the Bible is important in two ways. It indicates the historical probability of different aspects of the life and ministry of Jesus. Convictions about Jesus are connected to world history "in as certain a fashion as Julius Caesar" (162). Secondly, historical knowledge reveals the symbolic world of New Testament authors that "is both specific and massively different from our own." He strongly underlines that to ignore the bright light thrown on the New Testament by all the historical research of the past hundred years would be irresponsible, precisely because such knowledge expands and enhances our appreciation of the human Jesus discernible in its pages. (163).

There is, however, a difference between historical knowledge, with all its unavoidable restrictions and faith that seeks to read scripture in terms of its tranformative power, generated by the experience of the resurrection. Biblical studies, if it wishes to understand these texts in terms of their experiential origins, should also reflect and promote the understanding of the Bible as a transformative text. With this, an important aspect of this book is addressed, that now needs more discussion.

\section{The Role of Spirituality}

What makes Johnson's contribution unique, though, is that his approach is not merely another "theological" reading of the Bible - interpreting the historical events in terms of their theological thrust or nature. It goes much deeper than this, implying a spiritual event:

Unless in some fashion I am in touch with God's intrusion into my life..., there is nothing for me to think of at all that I can call theology. If the shaping and sanctifying work

scholars who focus on the New Testament as a book of the church. Scholars who pursue one of these approaches often regard the other as legitimate forms of study. The approaches only become controversial when their institutional character is debated: those who study Biblical texts at universities, for example, would claim that their academic setting requires a comparative approach and that a specifically Christian study of the texts or an ecclesial hermeneutics should only be part of a seminary setting. 
of the Holy Spirit is not the essential starting point and final goal of the theological process, then I cannot but regard the "spiritual life" as an effete form or super-erogation (5).

Historical facts regarding past events are not the starting point of the discipline - but the spirituality of the scholar is.

If we are to know which questions to pose to which texts, we need to be alert first of all to the shape of our experience before God. God's work in our lives is the leading edge of an ecclesial hermeneutic (8).

What is the shape and consequences of "our experience before God"? This book starts with reflections on it ("Theology and the Spiritual Life," 3-10). Spirituality fundamentally determines theology. Theology has an experiential basis, since it has to do with "the alien, surprising and awesome intrusion of the Holy into our lives, smashing our preconceptions and models of holiness alike with brutal calm (3; also 5), so that "the shaping and sanctifying work of the Holy Spirit is ... the essential starting point and final goal of the theological process" (4; secondary italics).

One understands that in the context of this book that wishes to communicate with the believing church community, these remarks make much sense. But in this book Johnson is not merely trying to revive difficult theological research in order to get lay people to become interested in it. Analysing the notion of knowledge, he reshapes the traditional position that we first have to "know" the text as a book of a complicated past, before we can interpret it theologically. Writing about the eucharist, Johnson thus finds it necessary to observe that the Gospels do not encourage the objective form of knowing that allows distance and detachment, but demand that deeply subjective form of learning that requires risk and intimacy (177).

He also presents a fresh perspective on theology. It is not about taking note of the thoughts of others about God. We are alienated when we study theology in order to know more about the faith of others than about our own faith. This is also true of our study of Scripture. We read Scripture in order to pose the question how its witness to a transforming power might be at work in us (7). "What is meant, experientially, by the obedience of faith (Rom.1:5; 16:26) and how does one learn obedience through what one suffers (Heb.5:510)?" (7).

This has nothing to do with sentimental feelings or selfhelp religion as if spirituality is about "human activity of seeking perfection by piety and practice" (3). We discover in scriptures, for example, what maturity in Christ means. Noting both the theological and spiritual implications of this concept, he asks rhetorically, "Does the growth granted by the Spirit move us toward the perfectionism of the ascetical, or the availability of faith?" Pursuing the spiritual life is not a pleasant option, it is "dangerous stuff.... When we are called to attention by the Holy, we are involved in idolatry and faith, sin and grace, slavery and freedom; within the tangled, complex and resistent fabric of our lives" (4). Thus the theological is essential and necessarily transformative in its effect. And in this way, spirituality becomes the larger framework and driving force of our hermeneutical activity.

It is in line with this that prayer becomes the very essence of the life of faith (136). It enables the life of faith because it is the fundamental "conversion," a turning point from the measure of the world and its power to the Word of God and its power (137).

The world finds its proper celebration as God's creation by turning in prayer to God who sustains everything.

In terms of this spirituality, salvation is not understood in oversimplified terms as either a flight from the world or a restructuring of the world, but in terms of the patient living through a complex life together in the world. Just as Jesus shows us a God who saves all humans by entering fully into the fabric of a highly particular human existence, defined and 
constrained by a specific time and place, and just as Jesus shows us a brother whose faith in God and love for others reveals the right direction of human freedom played out in the tangled web of difficult and intractable social realities, so are those who live "by faith of the Son of God who loved us and gave himself for us" (Gal.2:20) convinced by Paul's words that "with fear and trembling you are working out your salvation, for God is at work in you, both to will and to work for his good pleasure" (Phil.2:13).

Once salvation is defined in this focussed way as relating to a Christian art of living, as having to do with complex relationships, one is in the heart of what is traditionally known as spirituality. Salvation, a key theological concept is linked with faith and then understood as involving risk and obedience to God. This, in turn, has major consequences in terms of such serious issues as the theodicy problem and relationships with the other, as is clear from other parts of this book. In the second essay (Suffering, Sin and Scripture; 11-18) Johnson powerfully questions the way in which suffering is regarded as evil in our contemporary society. He portrays Jesus as someone who compassionately suffers with and for other in order to empower them with life (16). Suffering is thus an expression of selfemptying love. And then, daringly, Johnson talks about the image of God in Christianity as the ultimate expression that "suffering change is the price paid for life to grow," so that suffering is "at the heart of God's own life" (17). Thus suffering does not destroy life, but creates it! With this the transformative qualities of Biblical spirituality are spelled out. Faith, one dares to say, is not threatened by suffering, but is even formed by it. The art of Christian living is to look at suffering differently than our tired, selfish world.

Biblical texts document and portray transformative faith experiences. Ecclesial hermeneutics live off this insight. This is how Biblical texts want to communicate with us. At the same time, our own contemporary faith experiences help us revitalize Biblical passages and symbols. Thus we reembrace the Biblical notion of sacrifice by noting how it is illuminated by the fact that people in contemporary society sacrifice their own well-being and possessions to make others that they love, happy. Parents give up and sacrifice much in order for the happiness of their children. "Often we end up without even a spot on the couch we can call our own" (33), he writes with humour. Though we experience how our children take things away from us, we also realize that they bring in "larger and infinitely more fascinating forms of life ('Tiffany took her first steps. Kim got married. Joby made a recording'." 33). But, then, developing this motif even further, away from cheap moralism, he argues that sacrificing needs to be understood not as a matter of giving so that we may get, but as giving because of the gift we received from God in faith.

The historical critical approach replaced a biblical theology that illegitimately and anachronistically imposed later dogmatic readings on the texts or treated them ahistorically. Thus historical criticism also helped to remove the misunderstanding that the Bible is to be understood in terms of an abstract, idealist set of propositions. Historical research proved that Christianity was a complex and multifaceted movement with many faces in different locations. It is legitimate to investigate this complicated movement in terms of some original historical events and in terms of a historical Jesus. In the end, though, this is only one possibility of approaching the texts in all their complexities. By focussing on the faith experience that undergirds, frames and reflects the gospel narratives and their historical world, Johnson introduces the category of experience as another perspective on and explanation for the multifaceted nature of Christianity. This spirituality motif, often linked with the notion of freedom, complements the historical approach, challenges it on important point and opens up new avenues of research. This book explains why and then and in addition, also provides material for further research. 


\section{Homosexuality}

A good illustration of how spirituality permeates the interpretation of Scripture and reflection on ethical issues, is found in Johnson's discussion of homosexuality. This example will also show how spirituality can help provide new answers to old problems. Spirituality should not be misunderstood here in the sense that Johnson merely calls for the debate to be characterized by compassion. It comprises much more, although the remarks of Johnson also reflect the rejection by Hays, one of the well known ethicists of our time (1996:379406), ${ }^{7}$ of any form of homophobia and self-righteous condemnation of others.

That Johnson's position promises to help overcome the impasse on the debate about homosexuality, is clear when one compares it with the views of Hays (1996:389). Hays argues that Biblical texts reject "homoerotic activity" unequivocally. This position is shared fully by Johnson:

I think it is fair to conclude that early Christianity knew about homosexuality as it was practised in Graeco-Roman culture, shared Judaism's association of it with the "abominations" of idolatry, and regarded it as incompatible with life in the Kingdom of God. The auctoritates emphatically define homosexuality as a vice, and they cannot simply be dismissed (63).

One should, however, understand the complexities involved here. Other than Hays, Johnson finds the fact that there is a paucity of Biblical information on homosexuality significant, leading to the impression that "the off-handed rejection of homosexuality appears instinctive and relatively unreflective" (63). With this important remark, Johnson helps us to understand what many exegetes up till now felt intuitively, but failed to formulate clearly. Whilst it is true that some Biblical passages reject promiscuous sexual behaviour, he is correct that one should compare the paucity of these condemnations with the many strong rejections of economic oppression in the Bible, some of them in the heart of the Gospel message (e.g. Lk.6:24!). The Biblical injunctions against economical exploitation is exactly not "instinctive" and certainly purposefully reflective - illustrating his point about the paucity of Biblical references to homosexuality well. This remark of Johnson represents one of the few times in modern exegesis that the limited discussion of the topic of homosexuality in the Bible is taken seriously and accounted for hermeneutically.

It is further also, as Johnson adds in terms of hermeneutics, instructive that the Bible most frequently and flatly rejects any form of promiscuous sexuality rather than any of its specific manifestations. In other words, if and where the Bible is preoccupied with immoral sexuality, it is because of and especially with regard to its promiscuity.

But the discussion is even more complicated than this. It is, for example, generally accepted in Biblical ethics that ethical decision making should be based on more than exegesis of particular texts. In the case of homosexuality, there is not only a paucity of material, but, as Hays notes, the Bible also yields a minimum of additional rules, ${ }^{8}$ principles ${ }^{9}$ and paradigms ${ }^{10}$ that could complement the analysis of this material. One

\footnotetext{
R Hays, The Moral Vision of the New Testament Coomunity, Cross, New Creation: A Contemporary Introduction to New Testament Ethics. Harper SanFrancisco, 1996.

8 Hays (1996:394) notes that there is, strikingly, no clear rule against homosexual practices in the New Testament!

9 Hays (1996:395) argues that Romans 1 is ambiguous as a principle against homosexuality. This chapter demands that humanity should confess God as creator. Where homosexuals claim that they were created by God in this way, they are accepting this principle.

10 Hays (1996:395) notes that there are only three possible paradigms on homosexuality in the New Testament (Rom.1:18-32; 1 Cor.6:9 and 1 Tim.1:10), and then describes this as "slender" evidence.
} 
further does not find much more help in terms of other post- or non-Biblical authorities that guide the ethical decision making-process (e.g. tradition, reason and scientific studies). ${ }^{11}$ Hays does refer to modern experiences as such a guideline, ${ }^{12}$ noting that such experience indicates that stable, loving homosexual relations do exist. This would seem to allow for an acceptance of homosexuality. In this case, though, Hays argues that this positive experience is outweighed by the reported negative experience of other gay people who are disillusioned with a gay lifestyle. He writes:

...the church must not overlook the experience reported by those Christians who, like Gary, struggle with homosexual desires and find them a hindrance to living lives committed to the service of God (399).

It is on this point of experience that Johnson's book is specifically relevant. He also finds the notion of experience important, but develops it differently than Hays. For him it is decisive to conduct a careful textual reading of passages on homosexuality in terms of the transformative faith experience of the early church. In the light of its faith experience, the early church exercised amazing freedom to abandon, reject or change existing and fundamental social traditions at some seminal moments of its history. It, for example, abandoned major Biblical purity regulations and accepted gentiles in its midst, despite the strong opposition of leading apostles like Peter.

This use of experiential reality by Johnson rejuvenates historical analysis and illuminates the major consequences of historical events. It helps modern readers to appreciate more fully the radical nature of historical changes in Biblical texts. Thus Johnson's historical analysis shows how painful it must have been for those early Christian believers to accept Gentiles in their midst. This is evident in Peter's horror at seeing in his divine vision the unclean animals and hear God's instruction to eat them (Ac.10:13-14). Luke, notes Johnson further, had to use as much as a fifth of his long book (Ac.10-15) to describe this difficult struggle and to note how extensively it occupied the life of the church in that particular phase of expansion and consolidation.

It is not difficult to agree with him on this. His comments are supported by a wider theology of change that accompanies the new experiential reality of early Christians: Their decision to accept Gentiles, radically affected their own lifestyle and identity. The church moved away from understanding its own identity in terms of blood: not circumcision, but faith in Christ, not genealogy, but spiritual relationships, not flesh, but the Spirit determined who belonged to God's new people. Their earlier Jewish blood theology, represented in sacrifices and solidified in the major symbol of circumcision, was replaced by a transformed symbolic universe with new rituals and symbols. As a direct and concrete result of this, their private domains, their homes, had to be opened to people who were previously regarded as impure. Whilst contact with Gentiles earlier contaminated them in their religious duties, their religion now required them to become one with the outsiders. Basic convictions about their identity as born Jews, were being relativized. Faith experienced became the hermeneutical key, relativising a natural theology of genetics and birth into the people of God. Already John the Baptist firmly rejected any attempt to determine membership of the covenant in terms of a blood line (Lk.3:8). Paul confirmed this by showing how the relationship with Christ relativises gender (Gal.3:28). And it is

11 The strongest of these would be the church tradition, that condemned homosexuality for a long time. But then, Hays notes how a large body of modern studies regard it as a genetically determined trait.

12 In his essay on anti-Judaism and ethnic conflict (1996:438), for example, he writes how experience of Auschwitz and Nazism can play a "pivotal hermeneutical role" in discovering the fatal consequences of Biblical passages like John 8. "The role of experience, as we have noted earlier, is crucial in causing the church after the Holocaust to reassess its theology and its use of Scripture." 
well known how heated the debate about the eating of idol meat was in the early Church, indicating how aware many Christians remained of purity regulations and how long the debate about contact with the gentile world continued among Christians.

One can therefore hardly agree strongly enough with Johnson. The romantic picture in the minds of contemporary Bible readers of a church reaching out enthusiastically and lovingly to the Gentiles, obfuscates the real communication in Acts. This book presents a rather miserable picture of a church struggling to understand God's will on true grace and refusing to live the radical gospel of Jesus in all its implications for their own lives. Peter needs three calls (Ac.10:16!) before he understands what his vision means, only to discover that not only are Gentiles to be included in the church, but, even worse, that this must be done unconditionally. And it is only after a major meeting between the leaders of the church in Jerusalem, that the intense conflict on this issue is solved.

Johnson further develops this insight when he argues that the gay issue is analagous to the one facing earliest Christianity after Gentiles started being converted. Granted that they had been given the Holy Spirit, could they be accepted into the people of God just as they were, or must they first "become Jewish" by being circumcised and obeying all ritual demands of Torah?... The first century Mediterranean world was obsessed by the social implications of food and table-fellowship. The decision to let the Gentiles in "as is" and to establish a more inclusive form of table-fellowship, we should note, came into direct conflict with the accepted interpretation of Torah and what God wanted of humans (64).

What made the church change so dramatically? The answer is to be found in its transformational experience of historical events from the perspective of faith. Paul, Barnabas and Peter reported their personal observations about the special events among the Gentiles in Acts 15:4, 6-13. The early church thus experienced in a powerful way through signs and wonders how God required of it to be inclusive of the despised Gentiles.

Some exegetes (e.g. Hays) argued that one cannot use this experience regarding the Gentiles as argument in the gay debate because the new position about the Gentiles were partially formulated with the help of the universalist passages in the Old Testament. The experience of early Christians provided them with the correct hermeneutical lense on the Old Testament on the universal nature of the new people of God. But this argument is not convincing. There is more to this radical revision than simply embracing the Gentiles and a universal perspective. Christians also did not merely share the prophetic criticism of empty ritualism, but actually moved away from the sacrificial rites completely. Paul's position was not that circumcision should be retained in a more spiritual manner. Abandoning circumcision, an essential feature of Judaism and a mark of the covenant, represented a major, unprecedented change. There was nothing in the Old Testament that prepared for this. Nothing can be more radical than this abandoning of a natural order - as his Jewish colleagues, Peter and John, indeed experienced it.

From this, it is clear that the church always had the freedom to develop a new and unprecedented understanding of the gospel. And, more importantly, it was brought to and it motivated this understanding in terms of its faith experience. Christianity thus transformed the art of living in a manner that was unthinkable in previous times. This happened not only in the case of the Gentiles and ritual, but later on, in modern times, it happened also in the case of slavery and women. The church acted to liberate them - once again ignoring clear Biblical injunctions about the submissive position of these groups. There is materially no difference between accepting women as full and worthy believers despite Biblical passages like the damning 1 Timothy 2:12-14 and accepting homosexuals as full and worthy believers despite Biblical passages like Romans 1. 
To some extent these insights are being appreciated more and more in the church today. Thus some Christians seem to be willing to accept people with a homosexual orientation, but they still reject homoerotic activity. Their argument is that this is an offence against nature and God's (heterosexual) will for creation.

This is an important argument, and one that Johnson also addresses. He notes, however, first of all, that there is growing opposition of Christian homosexuals against the assumption that choosing a homosexual lifestyle implies a choice against what is natural and for a vice. In fact, from their faith experience about their homosexuality, homosexual Christians claim that God created them in this way (as already mentioned above).

Obviously this raises the question about the nature of sexuality as a physical phenomenon. To answer this question, one has to take cognisance of the nature of sexuality in the Bible in general. In the New Testament sexuality is always integrated in a spiritual framework. One's spiritual calling, for example, may require that one has to remain unmarried, as Paul asserts. This raises the question when sexuality is moral or immoral something that Johnson formulates as follows:

Is the moral quality of sexual behaviour defined biologically in terms of the use of

certain body parts, or is it defined in terms of personal commitment and attitudes?

Johnson thus changes the traditional question (is homosexuality an offence against nature?) to the following question:

Are homosexuality and holiness of life compatible? Is homosexual covenantal love according "to the mind of Christ," an authentic realization of that Christian identity authored by the Holy Spirit, and therefore "authored" as well by the Scripture despite the "authorities" speaking against it? The Church can discern this only on the basis of faithful witness. ${ }^{13}$

The decisive question on homosexuality eventually is about the compatibility of a homosexual lifestyle and a life of holiness. It thus becomes a question about spirituality, about the nature of the Christian art of living. To what extent can the church, driven by the Holy Spirit who gives and generates faith, discern the presence of this same Spirit in a nonpromiscuous covenantal relationship between people of the same sex?

The yardstick is not merely what "the Bible taught" or what was good in earlier times. Such a fixation on the past in early Christianity would have made the writing of Acts impossible and would have required of Christianity to retain circumcision - as was indeed argued by some of the leader apostles like James and John.

The answer to the rhetorical questions of Johnson is clear: Even if it is true that Biblical stories about creation could be read as stories about natural determinacies, the New Testament overrides this with the more fundamental belief in the Gospel of salvation as norm for membership of the people of God and for a moral lifestyle. Faith is not determined by, but determines natural determinacies. Faith requires that we live a sober sexual lifestyle, that our sexuality is expressed in a holy manner. Those who exclude and victimize people with a homosexual lifestyle from humanity and the church, promote the same theology that perpetrated apartheid and Nazism where racial prejudices became determinative and eventually served as a yardstick for human identity and condition.

Thus the real issue for the church is not what is natural, but how faith forms and steers the natural. What is Jew or Greek, male or female, is relativized and what counts is faith, being in Christ and having put on Christ. A follower of Christ is not someone born of Abraham. Who belongs to Christ, becomes the new people of God as seed of Abraham

13 Note the extensive spirituality terminology in this quotation. 
(Gal.3:29). Thus they are no longer circumcized, but baptized. What counts in the eyes of God is not nature or how God created humanity, but rather how nature is redefined by faith, how it is experienced and lived in Christ. Nature is radically renewed in Christ (Rom.8:18-19) - to such an extent that it will experience a time in future that there will be no marriage (Mt.22:29-30). Those who are in Christ, live differently. Their sexuality is in the final instance not determined by creation or biology, but is modelled in the first instance on his ministry, characterized by a loving relationship of self-sacrifice and loyalty.

Finally, as Johnson observes, the issue of gay people in the church has nothing to do with what they experience about themselves or with giving in to popular demands. Reflecting and deciding about this issue, is not about human experience, but about religious experience (63). The decision about this matter need to be made in terms of what God wants and does, just as the early church changed because of what God did among Gentiles, and not on the ground of what Gentiles claimed for themselves. The challenge is whether the church will recognize the renewing deeds of God and will resist it. Great leaders of the past did so, only to discover that their resistance amounted to disobedience and was futile. Others, like Paul, understood the will of God and won the world with his message of God's inclusive love.

\section{Conclusion}

In this new publication, the growing trend towards a theological reading of the Bible is confirmed and developed by a singular focus on spirituality. It integrates historical scholarship on the Bible in an interesting and fulfilling manner with the art of Christian living. The significant role of the transformative faith experience is developed in a special way to enrich the understanding of the Bible. It is a book that provides many insights worthy of further reflection and research. 